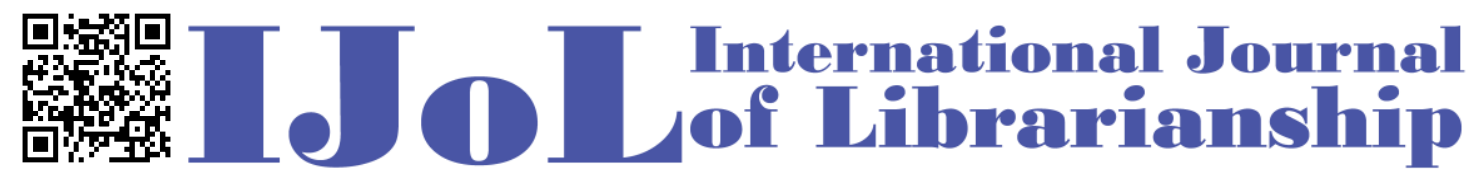

ISSN: 2474-3542 Journal homepage: http://journal.calaijol.org

\title{
Know Your International User behind the Screen: A Conversation among Chinese Students and Librarians Regarding Virtual Reference Services (VRS)
}

Xiaojie Duan

\begin{abstract}
:
Librarians need feedback from users to improve library services. On the other hand, users need assistance from librarians in order to gain a better understanding of library services. This paper focuses on how Chinese students use U.S. academic libraries' virtual reference services (VRS), and how academic librarians use VRS. By collecting data from Chinese students and librarians, this paper hopes to create a better understanding of these two factors in order to improve VRS.
\end{abstract}

To cite this article:

Duan, X. (2019). Know your international user behind the screen: A conversation among Chinese students and librarians regarding virtual reference services (VRS). International Journal of Librarianship, 4(2), 34-75.

To submit your article to this journal:

Go to http://ojs.calaijol.org/index.php/ijol/about/submissions 


\title{
Know Your International User behind the Screen: A Conversation among Chinese Students and Librarians Regarding Virtual Reference Services (VRS)
}

\author{
Xiaojie Duan \\ The University of Southern Mississippi, Hattiesburg, Mississippi, USA
}

\begin{abstract}
Librarians need feedback from users to improve library services. On the other hand, users need assistance from librarians in order to gain a better understanding of library services. This paper focuses on how Chinese students use U.S. academic libraries' virtual reference services (VRS), and how academic librarians use VRS. By collecting data from Chinese students and librarians, this paper hopes to create a better understanding of these two factors in order to improve VRS.
\end{abstract}

Keywords: Chinese Students, Academic Librarianship, Virtual Reference Services, Scholarly Communication

\section{INTRODUCTION}

In the $21^{\text {st }}$ century, libraries have developed various ways to provide services to their users. Email, texting, online chat...these virtual reference services (VRS) ensure that libraries can provide a 24/7 service mode to its users. VRS are also remote services for users who cannot be physically be present in the library. Nowadays users do not need to come to an information desk, but they can still seek help from librarians: they can ask their questions via telephones, iPads, laptops, etc. The development of technology allows libraries to provide services under the trends of the Internet and digital environment. VRS also allows users to gain access to library services through more convenient ways.

Chinese students - as a large group of students studying abroad - are increasing dramatically. With more and more Chinese families becoming affluent (Qiang, 2011), Chinese parents are able to support the tuition of studying abroad for their children. Many Chinese students choose America because of the quality of higher education. According to the Open Door data of the U.S. Institute of International Education (Institute of International Education, 2017), there are $1,078,822$ international students enrolled in U.S. colleges or universities in 2016-17, showing a $3.4 \%$ increase when compared with the same data from 2015-16. Among those international students, $33 \%$ of them were Chinese, making China the country which sent the most international students to the United States. 
When Chinese students come to American universities, and thus when Chinese students become a group of users of U.S. academic library services, especially the VRS, it raises several questions: 1) Do Chinese students know VRS? 2) Why do they use VRS? 3) Are Chinese students satisfied with using VRS? 4) Are librarians familiar with VRS? 5) Are they satisfied with providing VRS to users? 6) Is it necessary to provide VRS, especially to international students? Since more and more Chinese students are coming to the U.S., this is an opportunity to discuss whether U.S. academic libraries should have VRS specific to Chinese students.

Above are the main questions that helped the principal investigator to establish a research project in 2017, which aimed to gain more understanding of Chinese students as well as librarians using VRS, their familiarity and satisfaction with the service, and their expectations. Moreover, the research questionnaire was designed into two versions for both students and librarians, so that it is easier to compare the research data from the two groups of subjects. This research study was also designed to include separate questions for the two research groups, which gives Chinese students and librarians the opportunity to answer questions related to their specific use of VRS. The following literature review demonstrates different opinions related to the advantages and disadvantages of VRS, Chinese students' information seeking behaviors and their use of library services, and librarians' efforts of serving international users via VRS.

\section{LITERATURE REVIEW}

\section{Virtual Reference Services (VRS)}

VRS, known as "virtual reference services," which consists of both synchronous (e.g. chat box, texting) and asynchronous (e.g. email) services, is a way to provide reference services via the Internet. VRS expanded quickly with the development of technology in the 21st century. According to the data of the National Center for Education Statistics (2014), by the end of fiscal year 2012, 77\% of U.S. academic libraries provided VRS to their users. Three years later, Yang and Dalal (2015) conducted a systematic review of VRS on 362 four-year colleges and universities in the United States and Canada. They found that $47.5 \%$ of the libraries provide chat services to their users, and $6.6 \%$ of libraries also provide instant messaging (e.g. Yahoo, Google Talk, MSN) reference services to users. Despite the vast implementation of VRS in academic libraries, however, there are always ongoing debates about the use of VRS.

It is true that implementing and maintaining VRS is sometimes expensive, that is why many Library and Information Science courses have designed case studies in the classroom to enable students - maybe librarians in the future - to come up with a plan to set up VRS in a library on a limited budget (Dalston \& Puliin, 2008). Through those case studies, students will learn how money affects the VRS and other departments in the library, and how the allocation of a VRS plan is important when providing VRS on a tight budget. Breidenbaugh (2006) agrees that a budget plan for VRS is needed, and it is necessary to have an evaluation of VRS so that libraries will know how the VRS performs, and how libraries can continue or even expand the VRS to their users, under a state-wide VRS environment. With the development of the technology, some libraries are trying to offer VRS through web 2.0 software, including the Utah State Law Library, 
which provides the VRS to users using free tools such as Facebook, Google Voice, Twitter, and so on (Cheney, 2010). Olivas and Chan (2013) also introduced cost-effective software that can provide remote library services to users, like LibraryH3lp and Openfire for instant messaging, Jing for screencast, and Google Talk for video chat. However, Young of the J. Clarence Kelly Library (2013) questioned the quality and reliability of using free software (e.g. Meebo) as VRS, and stated that "When the value of the service is assessed to be high, it should be budgeted" (p. 176). Coffman (2001) advised that libraries should select the right software for virtual reference services, since some of the software are not designed for VRS, "all of the software packages were developed for some completely different purpose" (p. 2). Kern (2009) also suggested libraries think about readiness - both internal issues (e.g. staffing, ongoing and planned projects, internal user needs, etc.) and external collaboration-when setting up VRS. Internal elements can drive the selection of VRS for the library, and sometimes the VRS software that fits collaborating institutions may not be the best choice for a single library.

In addition to selecting VRS software, it is also important to conduct research about usability in order to find the best way to serve users. Côté, Kochkina, and Mawhinney (2016) conducted research about the staffing structure of VRS in the library of McGill University. They discovered that their users are mainly students, and most of the users ask questions about local collections or services via chat window or through email. According to their findings, they did not recommend a consortial service model for their library, but rather staffing VRS in their own institution. Moreover, they recommended a librarian-only structure for staffing VRS, since the questions received by their librarians have a low rate of referral. Rich and Lux (2018) researched VRS usability in their libraries in Bowling Green State University, and they found that the chat box is a popular tool for their users to ask questions online. In order to promote the chat service, they designed the pop-up window on several library website pages so that users can click the "Ask Us!" link wherever they have problems with online resources. Unlike Côté's research, they thought student employees helped a lot in their library when the information desk received a large amount of questions via chat. They also added a back-up shift schedule for the chat service so that librarians could provide remote help as needed. Chow and Croxton conducted VRS usability research for five types of VRS frequently used in two university libraries in the southeastern U.S. They found that chat service ranked highest considering effectiveness, efficiency, and satisfaction. Moreover, they found that although students are familiar with texting for social communication, they still prefer to use chat, telephone, or email to ask questions. It may be due to the fact that students have to remember a specific number to text for help, and they need to use extra devices to send messages to that number. Chow and Croxton also suggested that other researchers let users test multiple VRS before taking a research survey, so that users can share their hands-on practices of each type of VRS. Last but not least, Coughenour (2017) shared her strategies of serving global users via VRS. She thought that confirming users' affiliation and access to library resources is very important, since many global users do not have registered access to library databases or websites. She also suggested that librarians should explain questions clearly and not use professional terms or jargon via VRS, since for some global users, English may not be their first language.

Other than the assessment of VRS usability, training for VRS can also be time-consuming, since a good VRS system must be correctly installed, maintained, and used. In the University of 
Nevada, Las Vegas (UNLV) Libraries, $83 \%$ of librarians indicated that a training for their chat reference service was necessary (Tucker, 2004). All librarians who attended formal training programs felt the training of chat reference service was very helpful. The UNLV then further developed a training program, which included software training, chat reference transaction training, and research training for librarians to become familiar with the online chat system. The Tampa Library of the University of South Florida (USF) also participated in a one-year, state-wide virtual reference service program, which required 4-6 hours per week for scheduling and training (Bishop $\&$ Torrence, 2006). After attending the one-year-program, librarians gained a better understanding of VRS, the USF Libraries increased service hours, and users showed a higher satisfaction with online services. A few years later, RUSA (2010) recommended that libraries should "secure a commitment from a sufficient core of stakeholders at all levels of the institution's management and staff to support virtual reference service from its first planning stages through implementation before any project is attempted" (p. 93), making sure that librarians at all levels have management and control of the implementation of VRS. A year after RUSA's guideline, Devine, Paladino, and Davis (2011) found that among 228 U.S. colleges and universities that participated in their research, $75 \%$ provided chat reference trainings via virtual reference transactions, while more than half of them also provided post-trainings for their librarians.

Although VRS provides remote services to users, the overall logistics of reference services have to be changed, since with VRS, librarians have to respond to both online and onsite questions. Shaw and Spink (2009) agreed to have a triage model for VR service, which classified reference questions into three levels: directional, strategy, and research. Furthermore, they suggested that different levels of questions should be answered by different library personnel. For example, library assistants can answer directional questions, librarians can answer strategy questions, and subject specialists can answer research questions. Dempsey (2011) at the Evelyn S. Field Library at the Raritan Valley Community College (RVCC) suggested rethinking the reference services model in her library by setting up the referral system at their check-out desk. Through the system, some simple questions (e.g. where is the restroom) can be answered by other library staff at the desk, while full-time librarians can answer other questions via online chat in their offices. If staff cannot answer a question, they can make a referral to their on-call librarian via online chat; then the on-call librarian will change their online status to "Unavailable" and help their onsite users. Utilizing student workers might be another way to find the balance between virtual reference services and traditional reference services. Student workers can also answer simple directional and technical questions, while letting librarians answer more in-depth questions. However, Lux and Rich (2016) recommend that student workers must undergo training, and Barrett and Greenberg (2018) agreed. Their institution, The Ontario Council of University Libraries (OCUL), offers the virtual reference mentorship program, in which mentees can learn more about "Ask-a-Librarian" (AAL), the work environment, the customer communication skills, etc. With hands-on practice and assessment, this program ensures that student workers can provide qualified virtual reference services.

Finally, as an important way to provide library services to remote users, VRS also requires collaboration from libraries, librarians and users. The Standards for Distance Learning Library Services (2016) identifies that a library must meet six categories of requirements, including equal 
service access for all users, academic adequacy, strategic planning, etc., in order to provide standard remote library services. Soleymani, Mojiri, and Zadeh (2017) expanded the requirements to include academic librarians by listing five categories of skills that an academic librarian must have when working in the era of information and communication technologies (ICT), including skills in digital communication, information literacy, accessing electronic resources, and so on. On the other hand, some argue that remote users also play an important role in VRS, since librarians and libraries need to know their users before they can provide them with services. Administering surveys is a good way to gather information, and Pantry and Griffiths (2009) found that the users' searching methods have been greatly changed in the Internet environment, and users prefer electronic resources over more traditional materials. The University of Iowa also conducted a survey for their off-campus students (Stephen, 2001), and they found that students have different preferences than what librarians had thought: VRS (especially web and email), electronic resources, and home-delivery services ranked at the top, while computer-assisted instruction and user education services ranked the lowest. The University of Iowa improved their VRS as well as webbased resources for their remote users based on the survey results. Twelve years later, the Sheffield Hallam University administered a survey to ask opinions from both their distance-learners (DLs) and academic librarians in the U.K. (Brooke, McKinney, \& Donoghue, 2013). The survey found that librarians and DLs have different understandings related to VRS and other library services: DLs are in favor of using email instead of instant messaging to ask questions, they are comfortable with using library services, and they are in favor of document delivery via email. Librarians, unlike DLs, use instant messaging more frequently, and they think DLs lack confidence in using library services. In addition, some libraries do not provide document-delivery via email. After the survey, both the DLs and librarians agreed to communicate more in order to learn from each other.

It is believed that VRS require assessment, time, staff, funding for maintenance, and cooperation in various aspects. However, a good VRS proves that a library can provide services successfully within the Internet environment, and a well-maintained VRS plays an important role in an academic institution's success (Edwards, 2018). Other research also supports the opinion that reference is the heart of library services, and technology-based digital reference services can increase user satisfaction to help build value-added library services to users (Jerome, Nkiko, \& Ifeakachuku, 2017).

\section{Chinese students}

There is much research related to Chinese students using academic library resources in the United States. Some individuals believed that Chinese students have language barriers, since English is their second language and they seldom practice English during their daily lives in their own countries. However, the most important concern may come from cultural barriers. For example, in the research of Kumar and Suresh (2000), they discovered that international students usually are unfamiliar with the campus environment and the U.S. education system, so they may be unaware of library services. Therefore, an international student liaison may be needed to help international students learn about library resources, services, and life on campus. Are Chinese students, like other international students, unaware of library services and how to use them? Lin (2005) shared her observation on newly arrived Chinese students at the University of California Davis, who were 
immersed in the U.S. academic library environment which they had not experienced previously. Lin noticed that the Chinese students often came to the library as a group. They could become very frustrated when asking some general questions, like how to use computers, where are the books in the library, where is the restroom, etc., and they seldom participated in library orientations. Lin expressed concern that these Chinese students were too shy to communicate with others and that they might not be able to experience all the services that the library could provide to them. Wang of the University of Alabama (2016) also observed that one of his Chinese research subjects displayed different cultural behaviors than his American classmates. The research subject wanted to take a nap at a library computer station. His classmates were surprised by this decision, as for American students, the library is a place for studying not napping, but for the Chinese research subject, "most Chinese students take naps when they are tired" (p. 622). Another concern stems from the information-seeking behaviors of Chinese students. Schmidt (2013) observed East Asian students - including Chinese students - in the Sciences and Engineering Library at the University of Massachusetts Amherst. He noticed that the East Asian students used Google and Google Scholar heavily when searching for academic resources. Rodriguez (2014) also observed the same behavior. Chinese students at the University of Pittsburgh (UP) usually searched for resources online through Google, because compared to PittCat (the library online catalog for UP Libraries), web-based search engines were faster and easier to use.

Another issue may involve Chinese students' awareness of VRS. In Deng, Yang, and Zhang's research (2014), they found that the awareness and the use of VRS among Chinese students was very low; some of them had never even heard about or used VRS. They concluded the reasons behind the data were that students were "unfamiliar" and thought VRS "unnecessary." Some Chinese students do not like to use VRS; they do not trust VRS, and they preferred to ask their friends or classmates for help. Song (2004) found similar results in international business students using the Business and Economics (B\&E) Library at the University of Illinois at UrbanaChampaign. In her research, $17 \%$ of the subjects were Chinese students, and VRS ranked the lowest (scored 2.8 out of 5) as the most important library service. Song thought that international students might not familiar with VRS in the U.S., as they were also not familiar with VRS in their own countries. Interestingly, twelve years later, Michalak and Rysavy (2018) conducted the same research in 2016. Out of 149 research subjects, $36.24 \%$ were Chinese students. It was surprising to see that the VRS still ranked the lowest (3.33 out of 5) as the most important library services for international business students. However, for Chinese students, the importance of VRS scored 4 out of 5, with "group meeting space" being the least important library service. This data may indicate that the awareness of VRS among Chinese students is increasing, and Chinese students are more inclined to ask questions online rather than going to the information desk.

\section{Librarians}

There are always debates about potential bias when librarians use VRS to serve their users. Furlan (2007) reviewed the research conducted by Shachaf, Pnina, and Horowitz in 2006 and found that it shows potential discrimination in library services when provided to different ethnic groups. In the study, 32 librarians were asked to answer reference questions from one ethnic group (African American, Hispanic, Asian/Chinese, and Caucasian) or one religious group (Christian, Muslim, 
and Jewish). The research showed that African-American and Muslim users received the lowest quality of library services, while the Christian and Jewish users received the highest quality of library services. However, Furlan also pointed out that there are limitations to the research, and some data that may reveal alternative findings have not been explained. Three years later, Shachaf, Oltmann, and Horowitz's research (2008) repeated this study and obtained quite a different result. They expanded their subject scope to 54 U.S. academic and research libraries, and by analyzing 324 e-mail reference requests sent by the research groups, they discovered that there was no difference between e-services provided by librarians regardless of ethnicity or religion; each research group received equal e-services in terms of courtesy, reliability, and timely response. Glaser and Kahn (2005) also agreed that when librarians and users are using online platforms that they cannot see each other physically. Therefore the digital environment may somewhat limit discrimination under the anonymity of the Internet. Tarulli (2018) suggested that librarians should be aware of their body language, inflection, and vocabulary in order to provide a balanced perspective "in all areas of librarianship" (p. 172).

Librarians keep developing VRS to better serve their users. For example, the China Academic Library and Information System (CALIS) started the Distributed Collaborative Virtual Reference Service (DCVRS) to serve the users of Chinese academic libraries in the early $21 \mathrm{st}$ century (Jin, Huang, Lin, \& Guo, 2005). The CALIS built the DCVRS system based on a twolayer structure (local system and central system) which contained a knowledge base, virtual reference desk, profile database, and question/patron manager at the two layers. Users could get both synchronous and asynchronous reference services through this system, and this system supported bilingual services in English and Chinese. The CALIS hoped that they could expand the language support for the system to serve diverse international students in China, and the CALIS was seeking collaborations from other countries to support the DCVRS system.

With the development of technology, Chinese libraries and librarians are able to provide easier-to-use and more up-to-date VRS to their users. Wei and Yang (2017) found that 84.6\% of 985 universities in China provided library services through WeChat — an app designed by Tencent, a Chinese company, where students can easily check out materials, sign up for library events, and ask reference questions through their mobile phones. Pun (2015) also noticed the use of WeChat in New York University Shanghai. He concluded that the app has more useful and unique functions than Facebook and Twitter, and can overall help libraries serve their users remotely. He also promoted the idea of conducting research on Chinese students using WeChat in U.S. academic libraries.

Librarians in North American libraries are also making a determined effort to use VRS to serve their international users. Lupien (2004) stated that providing bilingual virtual reference services was a way to reach libraries' international users. In Lupien's library, bilingual services were launched by creating library webpages in English and French. Additionally, Lupien mentioned that many libraries that were interested in providing services in French have chosen QuestionPoint, a software that can support multiple languages, including Spanish, Chinese, Korean, and Dutch. At the same time, the University of Illinois at Urbana-Champaign started to provide virtual reference services specifically to its Slavic and East European students (Cannon, 2005). 
Students could chat with a Slavic librarian online, and they could even browse information in Slavic via the library website. The Slavic librarian could also co-browse with the student to help them find library materials without taking screenshots.

Librarians also use VRS to serve their international distance users. One example includes The Rochester Institute of Technology (RIT) in New York, where the librarians created tutorials to introduce library resources and services for users of RIT international campuses in Croatia, Kosovo, and Dubai (Mee, 2013). RIT librarians also used Collaboration Grids to conduct live bibliographic sessions for their remote library users, and they designed the library website to show a cluster of LibGuides, especially for RIT international campuses. Additionally, librarians from the University of Colorado, Boulder (UCB) and the University of Oregon (UO), created vernacular language videos as virtual library tours to introduce their libraries, materials, and services $(\mathrm{Li}$, McDowell, \& Wang, 2016). The two libraries created 14 videos, 11 of them in five languages, and three of them in three languages including Chinese. These videos were uploaded to the library's YouTube channels. Students thought these videos were helpful for them to understand the library in native languages before they were able to come to the campus. They learned more about library materials (e.g. Asian collections in the two libraries) after watching the videos, and also developed positive attitudes towards librarians for creating videos specifically for international users.

The previous research mentioned in the literature review covered three important elements-VRS, Chinese students, and librarians - through various aspects. However, these concepts have not all been covered within the same study, and the focus is seldom on Chinese students' use and expectations of VRS. The purpose of this research is to reveal librarians' and Chinese students' perspectives and satisfaction with VRS. It is hoped that this research study will help to fill this gap in the literature.

\section{RESEARCH STATEMENT}

\section{Research Objectives}

Data was gathered from two groups of subjects: Chinese students and librarians. The purpose of this research is to explore how Chinese students use virtual reference services (VRS) in academic libraries in the United States, and how librarians use VRS to help their international users. This research covers the following concepts:

1. Understanding research subjects' experiences of using VRS;

2. Analyzing research subjects' satisfaction with librarians/students via VRS;

3. Gaining knowledge of research subjects' points of view related to VRS, library websites, the online library catalog, and other online library resources and services;

4. Exploring research subjects' expectations of current and future VRS.

A goal of this research is to compare the data from Chinese students and librarians. As a result of this research, Chinese students may gain a better understanding of VRS and other library services as well as resources, while librarians may learn more about their international users' expectations and use of VRS. This study aims to bring Chinese students and librarians together, to 
let them know more about each other, and share their opinions, suggestions, and expectations towards VRS.

\section{Research Methodology}

The research is conducted through an online questionnaire, which aims to answer four main questions, based on research objectives:

1. Understanding of VRS: Do Chinese students and librarians know VRS? Do they use VRS?

2. Familiarity of VRS: Why do Chinese students and librarians use VRS? What types of VRS would they like to use?

3. Satisfaction of VRS: Are Chinese students and librarians satisfied with the answers they receive and/or deliver via VRS? What is the relationship between the waiting time and satisfaction when using VRS?

4. Expectation of VRS: What are Chinese students' and librarians' expectations of current and future VRS? Is it necessary to provide VRS specifically to international students?

In order to answer the four main questions above, the questionnaire contained twenty-seven in-depth questions. The questionnaire consisted of two versions, one for the librarians and one for the Chinese students, since some questions were tailored specifically to each group. For example, if a research subject selected "Librarian" for the question, then he/she would answer the librarian version of the questionnaire, and vice versa. The questionnaire was organized into five parts: general information; understanding of VRS; satisfaction with using VRS; familiarity of using VRS and other library online resources; and expectations of VRS. The full questionnaire with standard consent forms and logistic display is in the article appendix.

This research has been approved by the IRB of the University of Southern Mississippi Libraries on July 7, 2017, which is effective until July 8, 2018. The data collection process started in September 2017 and ended in June 2018. During the first four months of data collection, 34 Chinese students and 14 librarians in the University of Southern Mississippi Libraries (the home institution of the principal investigator) answered the questionnaire. From January to June 2018, the questionnaire was distributed through various listservs, library association websites, library school forums, Chinese students and Scholars Association (CSSA) blogs, etc. Chinese students and librarians from universities other than the University of Southern Mississippi, including the University of Illinois at Urbana-Champaign, the University of California-Berkeley, University of Washington, etc., also answered the questionnaire. After the data collection process, 134 valid questionnaires were collected, and the data was converted into an Excel sheet for research analysis.

\section{Data Explanation and Research Findings}

Part 1: General Information about Research Subjects.

Chinese students' data. It is interesting to note that when answering the question, "Are you a Chinese student or a librarian?" only $14.50 \%$ of the research subjects chose "Chinese student." Although fewer Chinese students participated in this research, their answers to all research questions in these five parts also provide valuable data to be analyzed. 
In terms of educational background, 52.94\% of the Chinese students who participated in this research are pursuing a Master's degree. Furthermore, $17.65 \%$ of Chinese students are pursuing a Ph.D. Another $17.65 \%$ of Chinese students are pursing "other degrees," and the remaining $11.76 \%$ Chinese students are pursuing a Bachelor's degree. When asked what "other degrees" constituted, Chinese students answered "EMBA," "custom-made degrees," "Executive Program," etc.

Librarians' data. It seems that librarians are more interested in this research and they are more eager to know their international users, since $85.50 \%$ of the research subjects chose "Librarian" when answering the question, "Are you a Chinese student or a librarian?" For educational background, $88.39 \%$ of the librarians hold a Master's degree, $6.25 \%$ of librarians hold a Ph.D., 4.46\% of librarians hold "other degrees," and $0.89 \%$ of librarians hold a Bachelor's degree. For those who have other degrees, librarians answered "visiting scholar," "Doctoral All-ButDissertation," "Juris Doctor \& MLIS," etc., which means that some librarians are educating themselves not only in the Library and Information Science (LIS) field, but also in other disciplines.

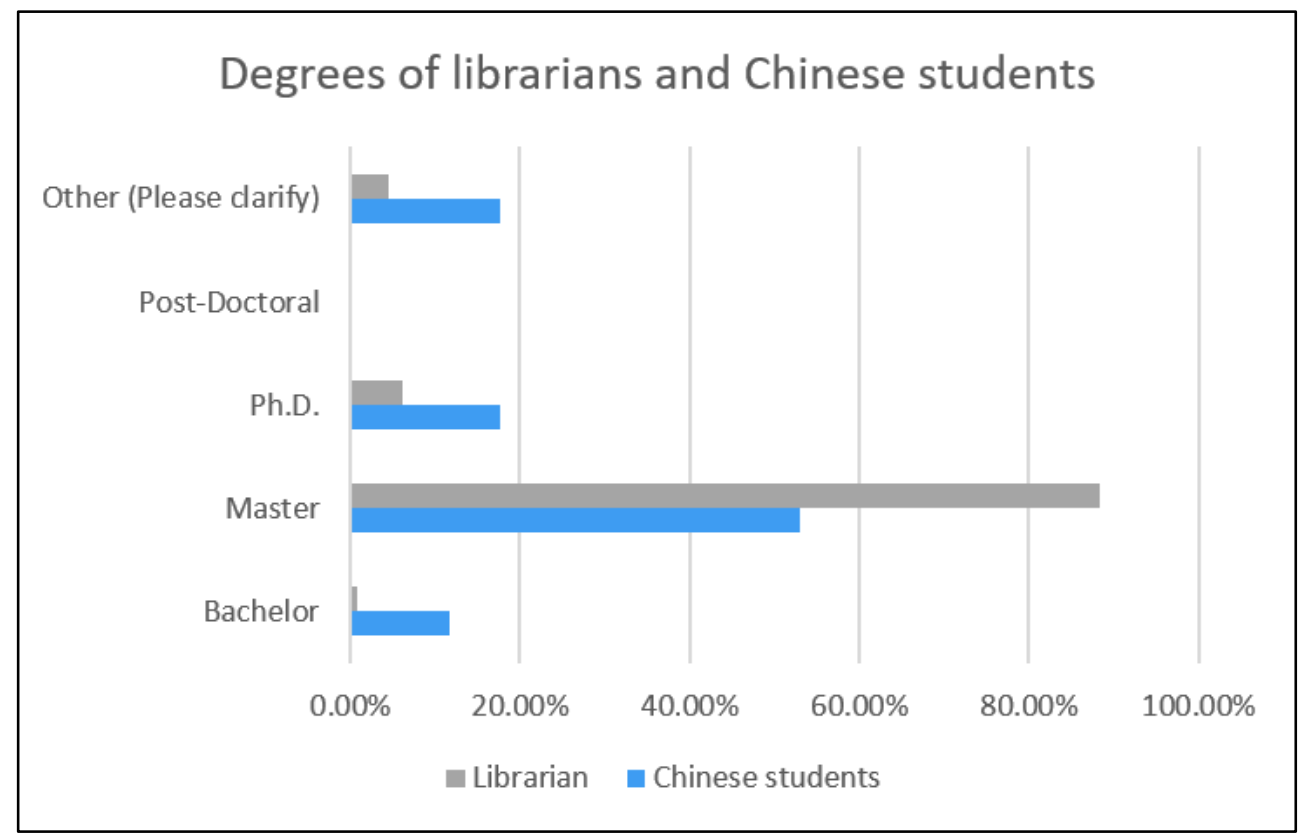

Figure 1: Degrees of librarians and Chinese students

The research data from the two research subject groups shows that Chinese students and librarians have similar trends in education: most of the Chinese students and librarians have Master's degrees. There are some Chinese students and librarians who have Ph.D.'s or other degrees. Furthermore, the research data indicates that librarians are capable of providing VRS to international users in terms of their educational backgrounds. According to the data, $88.39 \%$ of librarians have a Master's degree, which is also the most popular degree that Chinese students are pursuing. Other degrees have similar rankings: doctoral degrees ranked second for both librarians $(6.25 \%)$ and Chinese students (17.65\%), and Bachelor's degrees ranked the lowest $(0.89 \%$ of 
librarians, $11.76 \%$ of Chinese students). There are also $4.46 \%$ of librarians who have other degrees (e.g. dual Master's degrees). In summary, $99.1 \%$ of librarians who participated in this research have one or more degrees equal to or higher than a Master's degree, thus it is highly likely that an international student will encounter a librarian who has an MLIS or higher educational background when using VRS.

Part 2: Research Subjects' Understanding of VRS.

Chinese students' data. When asked "Do you know that your library provides virtual reference services (VRS)?" $88.24 \%$ of Chinese students chose "Yes," while $11.76 \%$ of them chose "No," and two Chinese students wrote, "I have never heard of VRS before." None of the Chinese students chose the third option: "I don't care whether my library provides VRS to its users." The data shows that many Chinese students know VRS and they know that their libraries are providing such a service to users. Some Chinese students, even though they do not know whether their libraries are providing VRS to users, still think it is necessary in a library. Although those Chinese students who do not know VRS may lack the experience of using it, they could become users after promotion. When asked "What types of questions have you asked most often through VRS?" $100 \%$ of Chinese students chose "academic questions," even though there are other options like directional questions (e.g. location of the library study room) and technical questions (e.g. how to use the library printer). The data shows that Chinese students use VRS for their academic information needs; they know that they can use VRS to find library materials for assignments. In addition, Chinese students may have varying reasons for not choosing directional or technical questions. For directional questions, if they want to find a library study room, they may need to go to the library and find the room physically; and for technical questions, if they want to print something through library printers, they should be there to use the machine. VRS is "useless" in these two cases; Chinese students may think it is more convenient to ask a librarian face-to-face if they have directional questions or technical questions under certain situations.

When asking Chinese students "What is the type of VRS that you used the most?" Online chat ranked the first (54.55\%), followed by Email (40.91\%) and Texting (4.55\%). The answers may relate to another research question, and the most straightforward one: "Why use VRS?" when asked this question, $34.92 \%$ of the Chinese students chose "VRS is faster and more convenient than traditional reference services," $25.71 \%$ of Chinese students chose "I am away from the library and cannot be there physically," and $22.86 \%$ of Chinese students chose "I am nervous when speaking with librarians face-to-face, it is better for me to ask questions online." Additionally, $17.14 \%$ of Chinese students chose VRS when they "do not need an instant answer, VRS can provide asynchronous answers to me." The research data indicates that Chinese students know the difference between VRS and traditional reference services, and they are benefiting from using VRS since they can ask questions without going to the library. Due to the fact that Chinese students know that VRS is "fast" and "convenient," they prefer to choose online chat, in which they can get answers instantly. And for some Chinese students who do not need instant answers, they choose email or texting. 


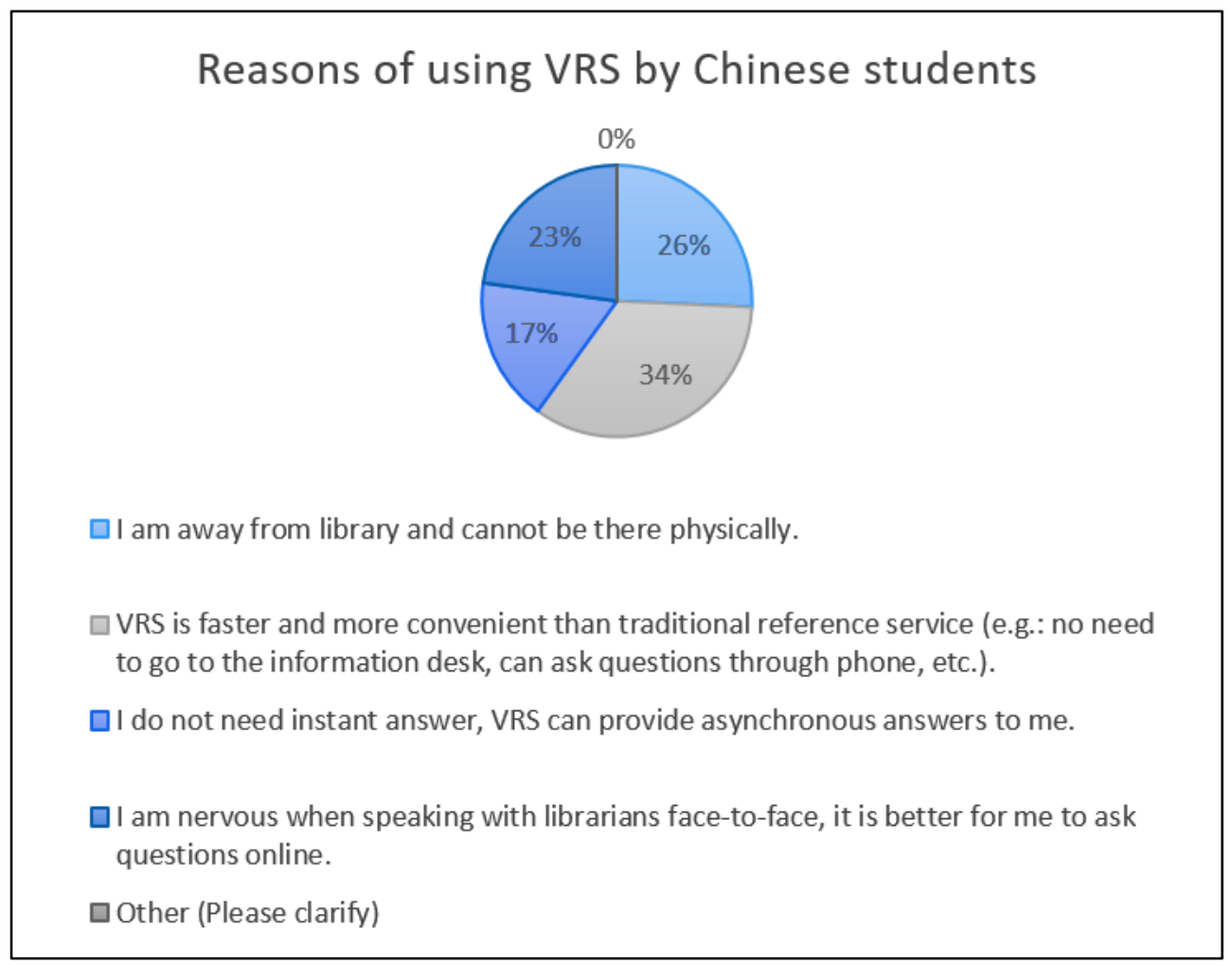

Figure 2: Reasons of using VRS by Chinese students

Librarians' data. Data collected from librarians shows that more and more academic librarians have duties other than reference services. When asked "Are you a reference librarian?" only 55\% of librarians selected "Yes," and another $45 \%$ of librarians selected "Reference is part of my job description." According to the research data, about one third of the librarians have other duties completely different than reference services, such as cataloging, circulation, and data analysis. Another third of librarians have duties closely related to reference services, such as instruction, research consulting, and faculty liaison. The remaining third of librarians are managers; they have administrative duties other than reference services, such as library assessment, collection development, and outreach. For example, one librarian surveyed is the Head of Technical Services, and they most likely supervise technical personnel in addition to reference duties. Another librarian surveyed is a library guide administrator and a library website designer, who is responsible for online libguide maintenance and web design. One librarian even wrote in the questionnaire: "We don't have a dedicated reference librarian." The explanations given for "other parts of job description" reveal that "librarian" is turning into a multitasking-oriented career. An assumption can be made that librarians have different duties according to library size and management. A big academic library can-and is required to-serve more users on campus. It is possible that academic libraries with bigger user groups may receive more support from their universities, and those academic libraries will have more "dedicated" reference librarians, who can focus on reference duties only. Medium-sized academic libraries and small academic libraries, on the other hand, may have less users than bigger ones. Consequentially, those smaller academic libraries may 
have less demand for recruiting librarians solely for reference duties, and their librarians thus may have more varied job responsibilities.

For librarians, there may be several reasons to not provide VRS to users. When asked "Does your library provide VRS to users?" $86.81 \%$ of librarians answered "Yes," but 13.19\% of librarians answered "No." Among the answers, "Lack of staff support" is the most popular one. Other reasons include, "Doesn't have Internet/technical support" and "Only provides in person or by appointment." The research data indicates that multitasking situations may contribute to the lack of VRS in an academic library, since multitasking librarians are sometimes busy with other duties instead of just watching the chat window. Without a dedicated person who can focus on VRS-related issues, while lacking the time and energy required to maintain and manage VRS, it may be difficult for some academic libraries to provide these services.

Another reason for not providing VRS may be due to user needs. For example, one librarian wrote down the reason for not providing VRS as: "The graduate students do not need this type of reference service very often." If users do not need VRS, it may not be necessary to provide it in an academic library.

In terms of the advantages of having VRS in an academic library, librarians think VRS shows "a way to provide reference service in an Internet environment," and VRS creates an opportunity that "allows off-campus users to use reference services." The third advantage is that VRS allows "different devices to be used," such as telephones or tablets. The research data indicates that librarians think VRS is convenient, and compared to traditional reference services, VRS offers a new way to provide reference services to users. Moreover, VRS allows off-campus users to ask questions without going to the library physically.

As far as disadvantages, librarians think VRS asks "the librarian to find a strategy to deal with VRS questions and face-to-face reference questions at the same time," VRS requires "money and energy to purchase, maintain, and update," and sometimes VRS is "not available" to users, for example when there is a power outage or the Internet is shut down across campuses. Librarians' understanding of the disadvantages of VRS somewhat explains the possibility of not providing VRS to users, since libraries with less librarians may lack staff support for operating VRS, and those libraries may also lack financial support to help maintain and update VRS.

Compared to Chinese students' data regarding the types of questions they ask through VRS, librarians receive more varied types of questions. According to the research data, $80 \%$ of questions received by librarians via VRS are academic questions, $18.57 \%$ of questions are technical questions, and $1.43 \%$ of questions are directional questions. The reason that librarians get more types of questions may due to the fact that librarians are not only serving Chinese students, but also serving other library users. For Chinese students, they may only have academic questions, but for other users, like professors, visiting scholars, technicians, etc., they may have questions beyond that of finding library materials for assignments. Another explanation may be the different understanding of different types of questions by librarians and Chinese students. For example, a "directional question" for librarians should be a question asking for a geographical location, but for Chinese students, every question related to "study" can be considered an academic question. 
Here is a simple question: "Where is the classroom?" As a librarian, this question should be a directional question; but as a Chinese student, it may be considered an academic question. "I find classroom for study, and I think all questions about study are academic questions," wrote one Chinese student in the questionnaire.

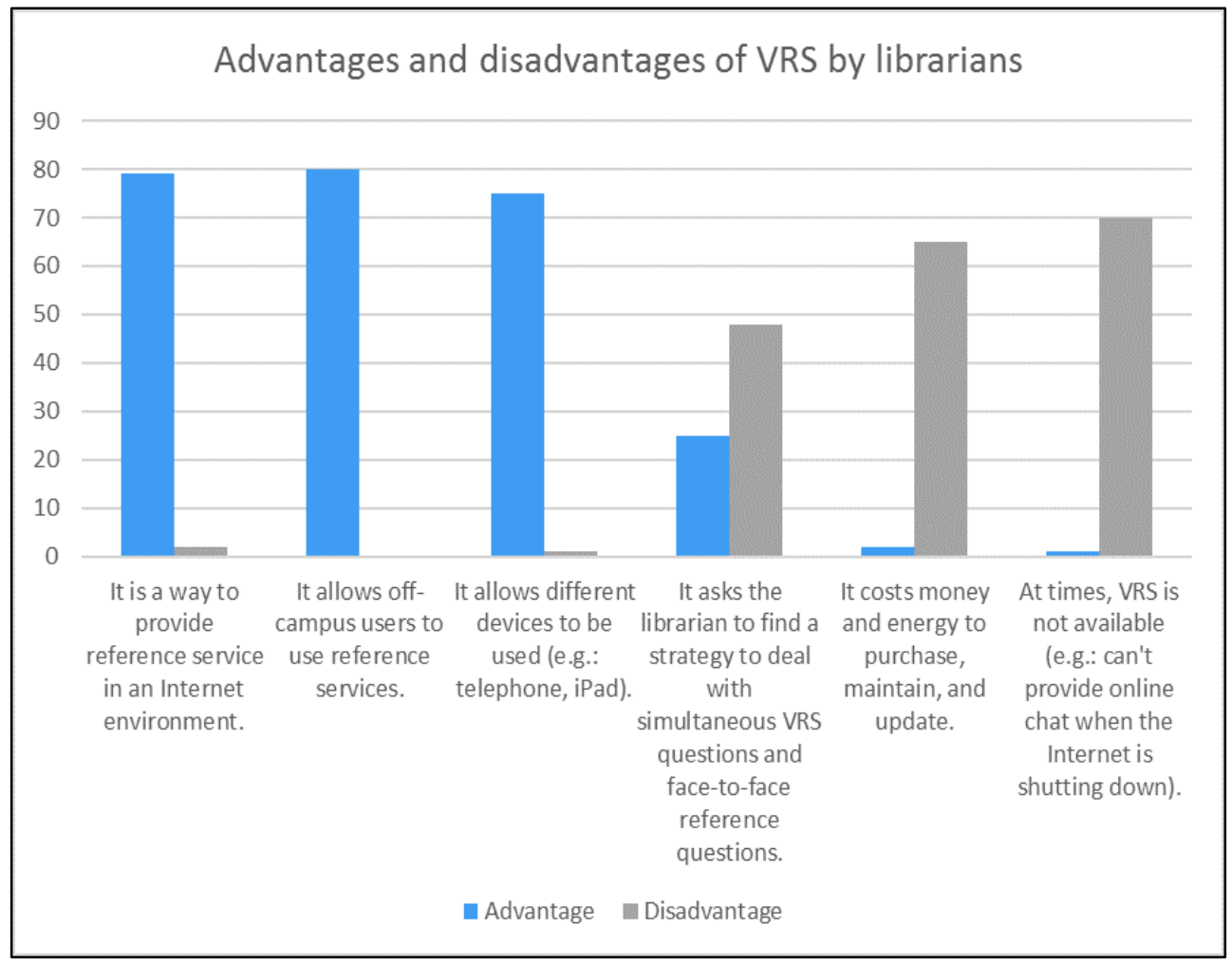

Figure 3: Advantages and disadvantages of VRS by librarians

\section{Part 3: Research Subjects' Satisfaction of VRS.}

Chinese students' data. The research data shows that Chinese students' satisfaction of VRS may be related to their English skills. By answering the question: "How satisfied are you with your English language when using VRS? Do you think your language skills cause trouble when using VRS?" Chinese students showed an overall satisfaction with their four English skills: English listening, English speaking, English reading, and English writing. None of them selected "Moderately dissatisfied and slightly cause trouble" nor "Extremely dissatisfied and does cause trouble" for the four English skills. Among the four English skills, Chinese students were most satisfied with English reading and writing skills. Each of these skills had the highest percentages in the category, "Extremely satisfied and does not cause trouble" $(23.08 \%)$, followed by English listening (15.38\%). It is notable that English speaking had the lowest percentage (7.69\%) under "Extremely satisfied." For the second level of satisfaction-"Moderately satisfied and might not cause trouble"-English reading and writing skills kept the highest percentage of satisfaction 
Table 1: Chinese students' satisfaction of English skills

(61.54\%), while English speaking ranked the third (46.15\%), and English listening ranked the fourth $(38.46 \%)$.

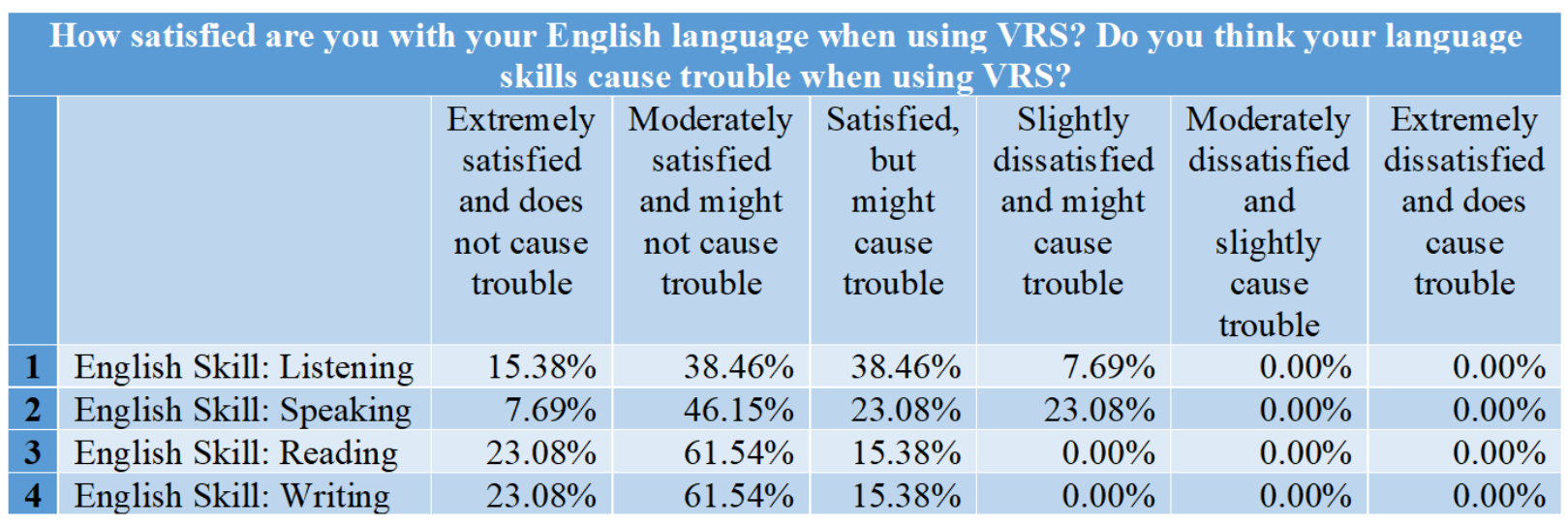

For the percentage of dissatisfaction, $38.46 \%$ of Chinese students selected English listening as "Satisfied, but might cause trouble," and 23.08\% of Chinese students selected English speaking for the same reason. English reading and writing skills had the lowest percentage (15.38\%) of "Satisfied, but might cause trouble." There were another $23.08 \%$ of Chinese students who selected "Slightly dissatisfied and might cause trouble" for their English speaking, and 7.69\% of Chinese students selected English listening as slightly dissatisfied. None of the Chinese students selected English reading and writing for slight dissatisfaction.

Chinese students' satisfaction of VRS also seems to be related to the amount of time they wait to receive answers. Generally speaking, the longer they wait, the less satisfaction they have. The questionnaire asked Chinese students to drag their level of satisfaction to the following time ranges: "1-3 minutes," "4-6 minutes," "7-9 minutes," and "more than 10 minutes." 40\% of Chinese students responded, "My questions have been solved and I am satisfied with the answers" under "1-3 minutes," 30\% of Chinese students responded, "Some of my questions have been solved and I am somehow satisfied with the answers" under "4-6 minutes." No Chinese students showed dissatisfaction with the two time ranges. But when the time range came to "7-9 minutes," 33.33\% of Chinese students responded, "My questions have not been solved and I am not satisfied with the answers." The percentage of dissatisfaction even doubled for the time range "More than 10 minutes," meaning that $66.66 \%$ of Chinese students were not satisfied with the answers at all if they waited for more than 10 minutes. It is a general practice for Chinese students to weigh the satisfaction of using VRS by the wait time, since the main reasons Chinese students choose VRS are that it is "fast" and "convenient"- they can get the answers as soon as possible. If Chinese students cannot get their answers in a reasonable timeframe, they may feel dissatisfied in using VRS. 


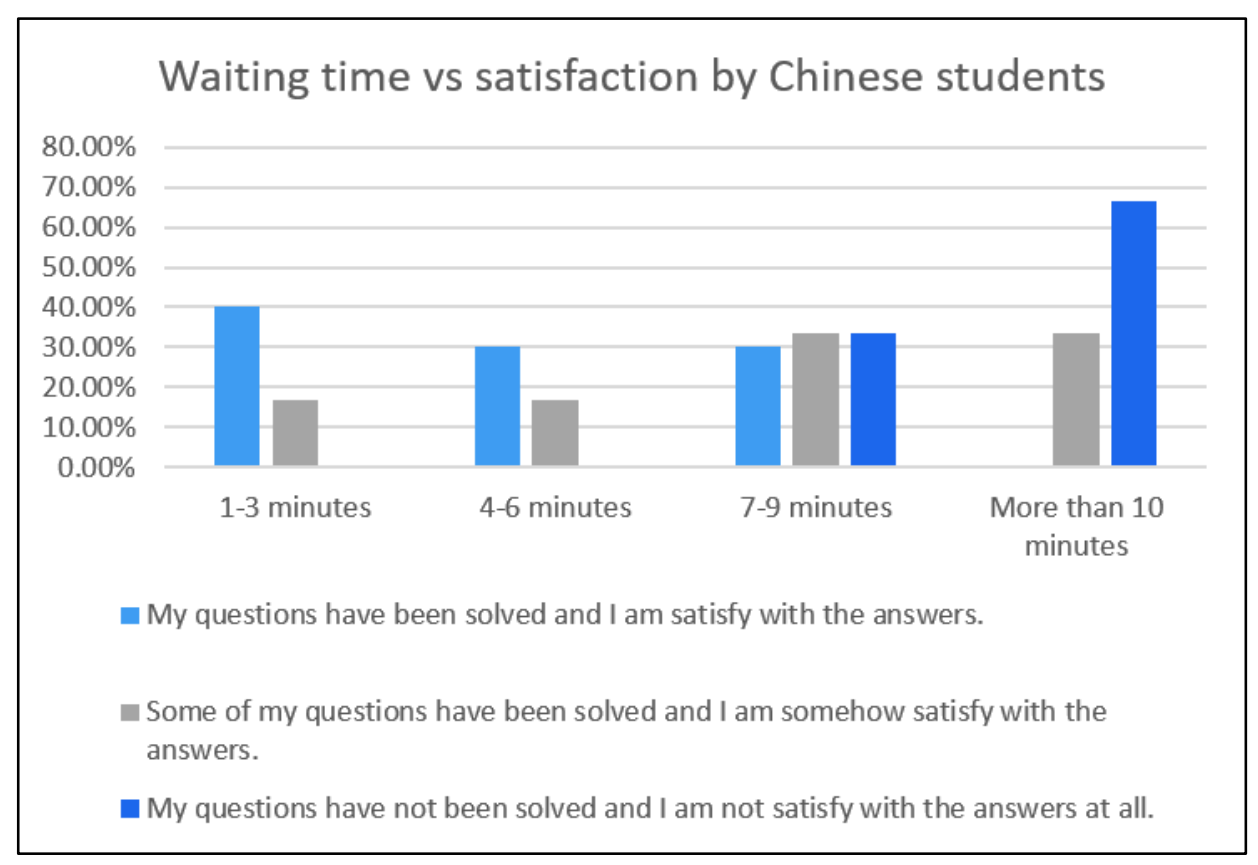

Figure 4: Waiting time vs satisfaction by Chinese students

Librarians' data. Librarians' data indicates a different perspective in the satisfaction of using VRS. According to the responses regarding wait time, librarians showed an overall satisfaction across the four time ranges. It is interesting to see that $28.99 \%$ of librarians responded "I am satisfied with my answers" for "4-6 minutes," making this the top-ranked time range, while "1-3 minutes" ranked second (26.09\%). "7-9 minutes" had 25.36\% satisfaction, and although "More than 10 minutes" ranked fourth, this time range still had 19.57\% satisfaction.

It seems that librarians' dissatisfaction of VRS did not coincide with time ranges, since three librarians responded "I am not satisfied with my answers at all" under "1-3 minutes," and one librarian responded with the same answer under "7-9 minutes." None of the librarians included this answer under "4-6 minutes," and only seven librarians included this answer under "More than 10 minutes." The research data shows that librarians' satisfaction is rather based on the quality of answers. For librarians, fast does not mean best; some librarians were not satisfied with their answers provided in 1-3 minutes at all, since a "qualified" answer requires time for thinking, searching, and explaining to the user. According to the data, most librarians think 4-6 minutes is a good timeframe - not too fast nor too long — which allows them to find answers and provide them to users. Time ranges "7-9 minutes" and "More than 10 minutes" have less satisfaction than time ranges "1-3 minutes" and "4-6 minutes," but the difference is not great enough to warrant being addressed.

Moreover, the time used for librarians to answer questions also varies for different types of questions. Librarians are not just answering academic questions; they also get directional or technical questions from users other than Chinese students. When librarians are not familiar with a specific type of question, they may ask for help as well, which may cause more time to wait from the other side of the computer screen. Also, when asked "Are you able to understand the question 
and provide the answer if the question has typographical or grammar problems?" Surprisingly, $54.32 \%$ of librarians answered "It depends," and another $45.68 \%$ of librarians answered "Yes." Even though no librarians answered "No," this research question indicates that librarians are willing to help users, but typo and grammar problems may cause difficulty in understanding what users really want to ask. Librarians may need to spend more time to understand such questions and this may delay the speed of delivering answers to users.

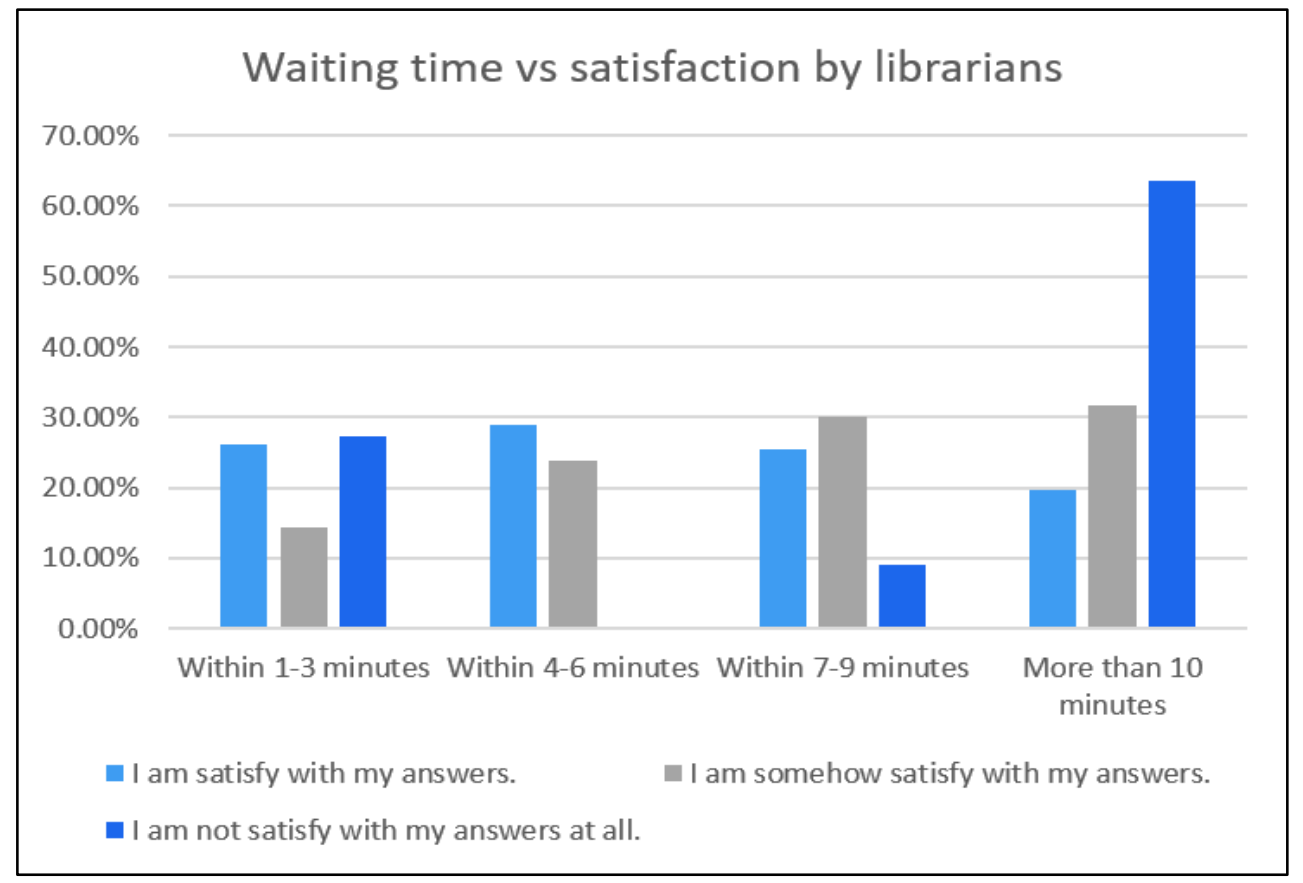

Figure 5: Waiting time vs satisfaction by librarians

Part 4: Research Subjects' Familiarity of VRS and Other Library Resources.

Chinese students' data. The questionnaire asked Chinese students to find VRS on their libraries' websites. The data shows that finding VRS is easy for Chinese students, since $93.33 \%$ of them confirmed that they could identify a service such as "Ask-a-librarian" on the website. Moreover, the questionnaire asked opinions from Chinese students about frequently asked question (FAQ) pages, research guides, pathfinders, etc., in order to understand how students solve problems by themselves if VRS is not available. In answering the question: "Do you think Frequently Asked Question (FAQ) pages, research guides, and path finders are helpful for you to find library materials before you ask for help?" $73.33 \%$ of Chinese students selected "Yes," they would like to go through FAQ pages, research guides, pathfinders, etc. before they ask a librarian for help. There were $20 \%$ of Chinese students who thought FAQ pages, research guides, pathfinders, etc. were not helpful because, "I prefer to ask a librarian first and she/he will tell me what to do." There was one student who selected "Maybe helpful" because "It depends on what questions I have. Sometimes I need those resources but sometimes I don't." The data shows that most Chinese students are familiar with other resources put on the library website, and they will use these resources to solve their problems first. However, the data also shows that some Chinese students 
prefer to ask librarians for help regardless of what the library has on the website, which indicates that some of the Chinese students rely on librarians rather than judging library resources for themselves.

The questionnaire also asked Chinese students' opinions of the online library cataloganother important way to find library materials on the library website. They were asked to score their familiarity with the library online catalog from 0 as "not familiar at all" to 5 as "extremely familiar." The average score was 3.4. Compared with their familiarity of FAQ pages, research guides, pathfinders, etc., Chinese students are less familiar with the online catalog. However, when asked "Do you search the online catalog before asking for help?" With zero meaning, "will not search the catalog first" to five indicating, "will search the catalog first," Chinese students gave a score of 4 out 5, which means they would be highly likely to search the catalog first before asking for help. The Chinese students' responses to this question may connect to their satisfaction with their English skills, since searching the library catalog requires English reading and writing skills, the two strongest English skills as reported by Chinese students. Moreover, when asked, "Are you able to find your wanted materials by using the library online catalog?" $90.01 \%$ of Chinese students selected "Yes," and when asked, "After you find your materials, do you still want to use VRS?" $70 \%$ of Chinese students selected "No." It is interesting to note that there were still $30 \%$ of Chinese students who would continue to use VRS after they found their materials; the reasons included, "I have other questions to ask librarians," and "I just want to make sure I found the correct material." The research data indicates that Chinese students have a basic understanding of the online library catalog, and most Chinese students will search this first to find materials by themselves. The data once again indicates that Chinese students trust librarians' understanding of library materials, since some Chinese students will ask librarians just for verification.

Librarians' data. In order to understand librarians' familiarity with VRS, they were asked, "Do you think users can easily find VRS through the library website?" $88.57 \%$ of librarians answered "Yes," they thought users can easily find VRS through the library website. $11.53 \%$ of librarians answered "No," because some libraries do not provide VRS to its users, or some libraries are lacking staff and technical support for VRS, as discussed in the reported disadvantages of VRS by librarians. The questionnaire also asked librarians to score their familiarity with VRS directly. From zero being "not familiar at all" to five being "extremely familiar," librarians gave a score of 4.35, which indicates most librarians are very familiar with VRS in their libraries.

When librarians were asked, "Are the 'FAQ' pages, research guides, path finders, etc. on the library website updated regularly? Do you think they can help users understand library services?" $76.25 \%$ of librarians selected "Yes," but there were $16.25 \%$ of librarians who selected "We do not only rely on these resources." Social media, library instruction sessions, workshops, webinars, etc. are some of the various ways that librarians are letting users know more about library materials and services. However, since there are various ways to ask for help other than browsing FAQ pages, research guides, pathfinders, etc., some Chinese students choose to ask a librarian directly instead of looking at the library resources first.

Librarians' opinion of the online catalog supported the $30 \%$ of Chinese students who would continue to use VRS after they found their materials. When asked "Do you direct users to the 
library online catalog and teach them how to search materials through the online catalog?" The top answer (46.38\%) was "It depends on the types of questions I get from users." There were $8.18 \%$ of librarians who preferred to give direct answers to users, and $7.27 \%$ of librarians preferred to provide other ways to find materials (e.g. interlibrary loan). Only $38.18 \%$ of librarians selected, "Yes, I often direct users to the library online catalog." Compared to Chinese students' data, it is a reasonable decision for librarians to not use the online catalog if users already used it to find materials, or if users have questions not related to finding materials. The research data also indicates that librarians are aware of additional ways to help users find materials besides the online catalog; they have a better understanding of library services than Chinese students, and they would like to help Chinese students and other users through various ways, based on different types of questions.

\section{Part 5: Research Subjects' Expectation of VRS.}

Chinese students' data. The questionnaire asked Chinese students what VRS specific to international students they would prefer. The popular answers included "More guides and videos of the library," "virtual tour of the library," "online chat in Chinese," "online translation," "Chinese server," etc. Chinese students even brainstormed other services that are not related to VRS, such as "workshops or short training courses for the use of database[s]," "library orientation," and "onsite library tour." However, some answers need further clarification. For example, for "guides and videos" and "virtual tours," do Chinese students prefer them in Chinese or English? How about workshops, orientations, and courses? Do they prefer them in Chinese as well? The research data shows that Chinese students are interested in VRS for international students, but it may not be necessary to provide such a VRS at this moment, since Chinese students' expectation is not only for VRS, but also for other library services.

Librarians' data. Librarians' data reveals a similar result. When asked "Do you provide VRS that focuses on international students?" $85 \%$ of librarians selected "No." When asked "What VRS would you like to add for international students?" Most of the librarians were hesitant to add specific services for international students since "we treat international students and other users the same," "we don't know if we're serving international students via VRS unless they tell us," and "all students are accessing the VRS through the same way." These results confirmed Shachaf, Oltmann, and Horowitz's research findings (2008) that librarians treat their users the same and they are providing equal services to all user groups. By using VRS, sometimes it is difficult to identify whether it is an international student or an American student behind the screen, since some international students may be highly proficient in English, while some American students may demonstrate typos or grammatical issues. However, even though $85 \%$ of librarians selected "No" for VRS specifically tailored to international students, the remaining $15 \%$ of librarians selected "Yes," and some of the libraries were providing WeChat (a Chinese software for instant messaging) as well as some other special research guides for international students. The research data shows that librarians may not be interested in providing VRS specifically for international students, but they are trying to learn more about their international users, and they are providing some services in users' native languages if it is necessary in their libraries. 


\section{DISCUSSION}

The discussion builds upon the main questions that helped to design this study, and the first question which should be discussed is the awareness of VRS by Chinese students. It is surprising to see that the research data shows a completely different conclusion than what others found, as discussed in the literature review (Deng, Yang, \& Zhang, 2014; Song, 2004; Michalak \& Rysavy, 2018). According to the research data for this study, Chinese students have quite a high awareness of VRS, since $93.33 \%$ of those who answered the questionnaire can identify a service such as "Ask-a-Librarian," on the library website. Chinese students are also aware of other online resources like Frequently Asked Questions (FAQ) pages, research guides, and pathfinders, and $73.33 \%$ of Chinese students will check these online resources before they request help from a librarian. Furthermore, Chinese students are also aware of the online library catalog - at least the average score was 3.4 when they have been asked to rank their familiarity from zero to five. Many of the Chinese students will also use the library online catalog to find their needed materials before they turn to a librarian for help: Chinese students scored four out of five when asked "Do you search the online catalog before asking for help?"

This study also examined the preference of Chinese students in regards to face-to-face reference services and VRS. Although there is no direct data of face-to-face reference services in this study, this information can be inferred by analyzing Chinese students' reasons for using VRS. According to the research data, $22.86 \%$ of Chinese students selected "I am nervous when speaking with librarians face-to-face, it is better for me to ask questions online," as one of their reasons for using VRS, making this choice the third most popular answer to the research question: "Why use VRS?" Although it is not the most popular reason for using VRS, the data still shows that some Chinese students are nervous when interacting with librarians verbally. These Chinese students may feel more comfortable using VRS than face-to-face reference services.

The preference between face-to-face reference services and VRS can also be analyzed through Chinese students' satisfaction with using VRS. According to Chinese students' answers to another research question: "What types of VRS that you used the most?" Chinese students used online chat the most $(54.55 \%)$ and email (40.91\%) ranked second. When asked whether they were satisfied with their English skills when using VRS, Chinese students had a high percentage of satisfaction with their English reading and English writing skills (23.08\% extremely satisfied and $61.54 \%$ moderately satisfied). Thus it is a reasonable assumption that Chinese students have higher satisfaction with using VRS via online chat or email because they can type their questions instead of speaking them out loud. Based on their reasons for satisfaction with using VRS, it is highly possible that Chinese students prefer VRS over traditional reference services.

The third discussion is the equity of providing VRS to users by librarians. Similar to what previous research had found as stated in the literature review (Glaser \& Kahn, 2005; Shachaf, Oltmann, \& Horowitz, 2008), the data in this study shows that librarians are treating their users equally, whether it is an American user or an international user. Additionally, the data shows that it is difficult to distinguish native English users from users for whom English is a second language, since librarians do not know who is using the VRS behind the screen. As one librarian answered 
in the questionnaire: "There's no way to know if we are helping an international student unless they tell us." Furthermore, when asked, "Are you able to understand the question and provide the answer if the question has typographical or grammar problems?" $54.32 \%$ of librarians answered, "It depends," which means librarians may need to verify the question before they can further help users. This question indicates that librarians are helping users based on the content of the question, not based on their nationality or their English skills.

The equity of librarians providing VRS to users can also be analyzed through librarians' expectations of VRS. According to the research data, most librarians (85\%) think that a VRS catering to international students may not be necessary. Some of the common reasons for this were: "We provide VRS to everyone," "There is only one chat service for all patrons," and "There are many students from all over the world, but we do not specifically focus on them." Another reason for not providing VRS specifically to international users may be due to the fact that some libraries do not have many or have no international users. However, there are still $15 \%$ of librarians who do provide VRS to international users, such as "WeChat," "a few specific research guides," "Chinese librarians doing VRS to Chinese students," etc. Based on the research data, it is believed that librarians are providing equal VRS to their users, with some librarians and libraries extending additional efforts to provide specific VRS to international users.

\section{LIMITATIONS AND FUTURE RESEARCH}

According to the findings and discussions of this study, one limitation is that there is no direct comparison between traditional reference services and VRS. Some discussions, including the preference of Chinese students between the two types of reference services, can only be assumed by analyzing the VRS research data. Furthermore, there is no direct comparison between librarians using the two types of reference services. Future research can be designed in which Chinese students and librarians use both traditional reference services and VRS, and then compare the two (e.g. let students ask the same question through online chat and face-to-face with librarians). Future research may also measure research subjects' familiarities, feelings (e.g. nervous or comfortable), and satisfaction with the two types of reference services.

The second limitation is the huge difference of participation between the two groups of subjects, as $85 \%$ of participants were librarians and $15 \%$ of participants were Chinese students. It is true that, compared to the number of librarians, the student population included in the research group is fairly small, thus the research data from Chinese students may have only covered students' understanding of VRS in a macroscopic view with little detailed information. Future research can be designed to only include Chinese students, and another questionnaire can be designed based on this study's survey template. The revised questionnaire can include more detailed questions to further explore the relationship between Chinese students' English skills and their use of VRS. Interviews can also be included in future research in order to obtain more detailed information about Chinese students' preferences for VRS and their reasons for choosing VRS based on their English skills. 
The third limitation is the design and the ambiguity of some of the research questions. The questionnaire has two versions, one for Chinese students and one for librarians. There are some questions which can be answered by both research subject groups; however, there are more questions which are specifically designed for one research subject group or the other. Therefore, it is time-consuming to compare data between Chinese students and librarians through multiple research questions. The ambiguity is demonstrated in one question particularly: "Are you a librarian?" For this question, $0.89 \%$ of librarians said they have a Bachelor's degree. Considering the fact that a Master's degree is a minimum requirement for academic librarians in the U.S., there may be a discrepancy between "librarian" as a profession and "librarian" as a word in the survey question. However, without further explanation of this survey question, it is hard to distinguish answers from professional librarians and paraprofessional personnel.

Future research can be designed to use only one short questionnaire with general questions, like degrees, ages, professions, etc. The short survey can have detailed options for research subjects to choose from, such as "librarian," "staff," "student assistant," etc. Then, for detailed information on the use of VRS, another short questionnaire can be designed for both groups of subjects. The second questionnaire will include multiple questions on the use of various types of VRS to search for library material, and the subjects' responses will be compared based on their familiarity with VRS. The second questionnaire can also include Chinese students asking the same questions via different types of VRS, and they will score their satisfaction with using each type. Librarians' data can be collected through the same way: by scoring their satisfaction with each VRS modality and recording their experiences with using different types to serve users.

\section{CONCLUSION}

This research was conducted through an online questionnaire about the use of VRS by two research subject groups: Chinese students and librarians. The questionnaire is designed to understand the general information of the two research subject groups, and furthermore their understanding, satisfaction, familiarity, and expectations of VRS. The detailed conclusions are included below.

First, Chinese students use VRS on a regular basis, and they mostly ask academic questions using VRS. Chinese students know the difference between VRS and traditional reference services. They believe VRS is fast and convenient. They prefer to use online chat and email to ask for help. Librarians use more types of VRS and they answer more types of questions besides academic questions; however, librarians also use online chat the most and they place an emphasis on academic questions.

Second, Chinese students' satisfaction is based on their English skills and the amount of time it takes for their question to be answered. Chinese students have overall satisfaction with their four types of English skills. However, they may feel more comfortable when using VRS that requires English reading and writing skills, and they may feel dissatisfied when using VRS using English listening and speaking skills. Also, the less time they wait, the higher satisfaction they have. Librarians, on the other hand, have overall satisfaction with providing answers through VRS, and their satisfaction is not based on the waiting time. Most librarians reported that 4-6 minutes is 
a reasonable timeframe to understand a question and deliver an answer to the user. Due to the fact that on occasion typos or grammatical issues will trouble librarians and slow down their reference processes, some librarians are satisfied with answers provided in more than 10 minutes.

Thirdly, Chinese students have a basic understanding of the library website, and they think the FAQ pages, research guides, pathfinders, etc., are helpful for them in finding materials. They know how to use the online library catalog to find materials, and they trust librarians' judgment of library materials. Librarians have a better understanding of FAQ pages, research guides, pathfinders, etc., and they are promoting these resources through various ways to users, such as social media, class sessions, workshops, and so on. Librarians also know how to use the online library catalog, but they tend to use different ways to help users, based on what types of questions they have.

Fourth, both Chinese students and librarians think it may not be necessary to create a VRS especially for international users. Chinese students have expectations for other library services as well: they want more videos, more workshops, or more webinars about library resources and library services, including VRS. Librarians treat international users the same as other user groups. Nevertheless, some librarians are also providing VRS especially to Chinese students, with services such as WeChat and VRS with Chinese librarians, showing that librarians are trying their best to create an even more accommodating VRS environment for Chinese students.

This research promotes two ways of improving VRS and other library services for those with English as a second language. One way may be producing textual materials (e.g. posters, flyers, blogs, and so on) to introduce library resources as well as providing services tailored to those users. This recommendation is based on Chinese students' satisfaction with their English skills. According to the research data, Chinese students are most satisfied with their English reading and writing skills, which implies that they prefer English textual materials. Furthermore, since Chinese students are not familiar with the online library catalog as compared to FAQ pages, library libguides, pathfinders, etc., those textual materials could give more detailed explanations of the online catalog, including how to use it and what type of materials it contains. Moreover, since some Chinese students will contact librarians after they found materials, it is also possible to put VRS not only on the homepage, but also on the search results page and other library webpages for convenient access.

Another way of improving VRS and other library services might be to produce audio and video materials for global users. This ties to the expectations of VRS and other library services by Chinese students, which includes "online chat in Chinese" and "virtual tour of the library." For those remote users who study in another country and cannot come to the campus physically, an audio recording or video which introduces library resources as well as services would be greatly beneficial. It may not be necessary to provide audio or videos in multiple languages, since the research data shows that "English listening" ranked third under "Extremely satisfied" by Chinese students. However, with a slight rate of dissatisfaction in Chinese students' English listening skills, the research suggests the use of subtitles in audio-visual materials if applicable, so that users with English as a second language can read the narration rather than just listening to it. 
By designing future research of VRS, it is possible to further understand Chinese students' preferences among different types of VRS and librarians' satisfaction of using different types of VRS. Overall, this research reveals various perspectives towards VRS from both the user side and the librarian side. It is hoped that this research will help Chinese students gain a better understanding of VRS, so that they can use it more efficiently and effectively. It is also hoped that librarians will understand their international users more, and thus find more ways to better serve them.

\section{References}

Barrett, K., \& Greenberg, A. (2018). Student-staffed virtual reference services: how to meet the training challenge. Journal of Library \& Information Services in Distance Learning, 12(34), 101-119. https://doi.org/10.1080/1533290X.2018.1498620

Bishop, B. W., \& Torrence, M. (2006). Virtual reference services: consortium versus standalone. College \& Undergraduate Libraries, 13(4), 117-127.

Breidenbaugh, A. (2006). Budget planning and performance measures for virtual reference services. Reference Librarian, 46(95/96), 113-124.

Brooke, C., McKinney, P., \& Donoghue, A. (2013). Provision of distance learner support services at U.K. universities: identification of best practice and institutional case study. Library Trends, 61(3), 613-635. https://doi.org/10.1353/lib.2013.0003

Cannon, A. (2005). Digital reference in Slavic and East European studies with an examination of practice at the University of Illinois and the Library of Congress. Virtual Slavica: Digital Libraries, Digital Archives, 183-217. https://doi.org/10.1300/J167v06n02_12

Chan, K. P., Colvin, J. B., Vinyard, M., Leach, C., Naumann, M. A., \& Stenis, P. (2015). Libraries across the sea: using a virtual presence and skilled student assistants to serve students abroad. Journal of Library Administration, 55(4), 278-301. https://doi.org/10.1080/01930826.2015.1038921

Cheney, M. (2010). Virtual reference: no budget? no time? no problem! AALL Spectrum, 15(2), 28-30.

Chow, A. S., \& Croxton, R. A. (2014). A usability evaluation of academic virtual reference services. College \& Research Libraries, 75(3), 309-361. https://doi.org/10.5860/crl13-408

Coffman, S. (2001). So you want to do virtual reference? Public Libraries, 14-20.

Côté, M., Kochkina, S., \& Mawhinney, T. (2016). Do you want to chat? reevaluating organization of virtual reference service at an academic library. Reference \& User Services Quarterly, 56(1), 36-46.

Coughenour, A. D. (2017). Virtual reference in a global context: going beyond local needs. Internet Reference Services Quarterly, 22(1), 55-62. https://doi.org/10.1080/10875301.2016.1276992

Dalston, T., \& Pullin, M. (2008). Virtual reference on a budget: case studies. Library Media Connection, 27(2), 30-33.

Dempsey, M. (2011). Blending the trends: a holistic approach to reference services. Public Services Quarterly, 7(1/2), 3-17. https://doi.org/10.1080/15228959.2011.572769 
Deng, S., Yang, L., \& Zhang, Y. (2014). Social Q\&As or library virtual reference: what is behind the choices of Chinese information seekers? Libri, 64(4), 327-340. https://doi.org/10.1515/libri-2014-0026

Devine, C., Paladino, E. B., \& Davis, J. A. (2011). Chat reference training after one decade: the results of a national survey of academic libraries. The Journal of Academic Librarianship, 37(3), 197-206. https://doi.org/10.1016/j.acalib.2011.02.011

Stephen, H. D. (2001). Knowing your users and what they want. Journal of Library Administration, 31(3-4), 177-193. https://doi.org/10.1300/J111v31n03_15

Edwards, E. (2018). Virtual reference: bridging the divide between in-person and digital assistance in academic libraries. ILA Reporter, 36(1), 26-29.

Furlan, W. (2007). Virtual racism rears its head: uncovering librarian bias in e-mail reference services. Evidence Based Library and Information Practice, 2(2), 97-100.

Glaser, J., \& Kahn, K. (2005). Prejudice, discrimination, and the Internet. The Social Psychology of the Internet, 247-274.

Guidelines for Implementing and Maintaining Virtual Reference Services. (2010). Reference \& User Services Quarterly, 50(1), 92-96.

Institute of International Education. (2017). International student enrollment trends, 1948/492016/17 [Data file]. Retrieved from https://www.iie.org/Research-and-Insights/OpenDoors/Data/International-Students/Enrollment

Jerome, I., Nkiko, C., \& Ifeakachuku, O. (2017). Value-added service to academic library users in 21st century: using competitive intelligence approach. Library Philosophy \& Practice, 118.

Jin, Y., Huang, M., Lin, H., \& Guo, J. (2005). Towards collaboration: the development of collaborative virtual reference service in China. The Journal of Academic Librarianship, 31(3), 287-291. https://doi.org/10.1016/j.acalib.2005.02.003

Kern, M. K. (2009). Virtual reference best practices : Tailoring services to your library. Chicago, IL: ALA Editions of the American Library Association.

Kumar, S. L., \& Suresh, R. S. (2000). Strategies for providing effective reference services for international adult learners. Reference Librarian, 33(69/70), 327-336.

Leistman, D. (2000). Reference services and the international adult learner. Reference Librarian, 33(69/70), 363-378.

Li, X., McDowell, K., \& Wang, X. (2016). Building bridges: outreach to international students via vernacular language videos. Reference Services Review, 44(3), 324-340. https://doi.org/10.1108/RSR-10-2015-0044

Lin, M. (2005). Library user services: what do newly arrived Chinese students need? Journal of East Asian Libraries, 2005(135), 1-9.

Lupien, P. (2004). Bilingual virtual reference: it's better than searching the open web. Computers in Libraries, 24(5), 6-8.

Lux, V. J., \& Rich, L. (2016). Can student assistants effectively provide chat reference services? student transcripts vs. librarian transcripts. Internet Reference Services Quarterly, 21(3-4), 115-139. https://doi.org/10.1080/10875301.2016.1248585 
Mee, S. (2013). Outreach to international campuses: removing barriers and building relationships. Journal of Library \& Information Services in Distance Learning, 7(1-2), 117. https://doi.org/10.1080/1533290X.2012.705173

Michalak, R. S., \& Rysavy, M. D. T. (2018). Twelve years later: comparing international business students' perceived use of physical and electronic library services in 2004 and 2016. Reference Services Review, 46(1), 42-68. https://doi.org/10.1108/RSR-05-2017-0014

National Center for Education Statistics. (2014). Percentage of academic libraries with selected electronic services, by control, level, size, and Carnegie classification of institution: Fiscal year 2012 [Data file]. Retrieved from https://nces.ed.gov/pubs2014/2014038.pdf

Olivas, A. P., \& Chan, I. (2013). Beyond the reference desk: a study on the effectiveness of lowcost distance library services at California State University San Marcos. Journal of Library \& Information Services in Distance Learning, 7(1-2), 40-52.

https://doi.org/10.1080/1533290X.2012.705177

Pantry, S., \& Griffiths, P. (2009). How to Give Your Users the LIS Services They Want. London: Facet Publishing.

Pun, R. (2015). WeChat in the library: promoting a new virtual reference service using a mobile app. Library Hi Tech News, 32(6), 9-11. https://doi.org/10.1108/LHTN-03-2015-0017

Qiang, Zha. (2011). The study abroad fever among Chinese students. International Higher Education, 69, 15-17. https://doi.org/10.6017/ihe.2012.69.8635

Rich, L., \& Lux, V. (2018). Reaching additional users with proactive chat. The Reference Librarian, 59(1), 23-34. https://doi.org/10.1080/02763877.2017.1352556

Rodriguez, E. R. (2014). Information-seeking behavior and the intercultural learning process: Experiences of international graduate students from China: A qualitative sense-making case study. Retrieved from ProQuest Dissertations \& Theses Global. (UMI 3582607)

Schmidt, M. G. (2013). East Asian students in a U.S. library: addressing expectations. 大学図書 館研究, 98, 26-33. https://doi.org/10.20722/jcul.196

Shachaf, P., Oltmann, S. M., \& Horowitz, S. M. (2008). Service equality in virtual reference. Journal of the Association for Information Science and Technology, 59(4), 535-550.

Yang, S. Q., \& Dalal, H. A. (2015). Delivering virtual reference services on the web: an investigation into the current practice by academic libraries. The Journal of Academic Librarianship, 41(1), 68-86. https://doi.org/10.1016/j.acalib.2014.10.003

Shaw, K., \& Spink, A. (2009). University library virtual reference services: best practices and continuous improvement. Australian Academic \& Research Libraries, 40(3), 192-205. https://doi.org/10.1080/00048623.2009.10721404

Soleymani, M. R., Mojiri S., \& Zadeh, M. H. (2017). The supporting roles of academic librarians in virtual education. International Journal of Educational and Psychological Researches, 3(4), 213-218. https://doi.org/10.4103/2395-2296.225095

Song, Y. (2004). International business students: a study on their use of electronic library services. Reference Services Review, 32(4), 367-373.

Standards for distance learning library services. (2016). Retrieved from http://www.ala.org/acrl/standards/guidelinesdistancelearning\#education

Tarulli, L. (2018). Bias in readers' advisory services. Reference \& User Services Quarterly, 57(3), 172-175. 
Tucker, J. C. (2004). Developing a chat reference training program. Internet Reference Services Quarterly, 8(4), 11-25. https://doi.org/10.1300/J136v08n04_02

Wang, M. (2016). The impact of cultural values on Chinese students in American higher education. Qualitative Report, 21(4), 611-628.

Wei, Q., \& Yang, Y. (2017). WeChat library: a new mode of mobile library service. Electronic Library, 35(1), 198-208. https://doi.org/10.1108/EL-12-2015-0248

Young, C. L. (2013). To be discontinued: a virtual reference cautionary tale. Reference Librarian, 54(2), 175-176. https://doi.org/10.1080/02763877.2013.75125

\section{Appendix}

\section{Questionnaire of librarians and Chinese students using library virtual reference services}

\section{Q1 Standard Informed Consent Form}

\section{$\underline{\text { Research Description }}$}

\section{Introduction}

This research attempts to collect information about international Chinese students' use of virtual reference services (VRS) in the US academic libraries and how librarians incorporate VRS into their daily workflow. The research will further explore both students' and librarians' altitudes and expectations with regard to VRS.

\section{Procedures}

This research is conducted by using an online questionnaire made by the Qualtrics, and the research project is expected to last for one year. Upon approval by the Institutional Review Board (IRB), the principal investigator will begin the data collection process. The questionnaire consists of twenty-seven questions in total. Participants will complete as many as fifteen or as few as seven questions, depending on their choices of answers. Participants will take five to ten minutes to answer the entire questionnaire. Questions are designed to let participants share their experiences of using VRS, their interactions with librarians/students, their understanding of/training in VRS, their points of view related to library website and library online catalog, and their satisfaction and expectations of current and future VRS. All data will be used only for research purposes.

\section{Risks/Discomforts}

There are no risks/discomforts caused by this research. There are no sensitive questions in the questionnaire (e.g.: name, gender, sex, drug usage, financial status, religious belief, etc.). The questionnaire will not link to your email address or other sensitive information and filling out the questionnaire is completely voluntary.

\section{Benefits}

This research creates an opportunity to compare the research data and get the research results 
from both students and librarians. For students, it is a way to share the VRS experiences and expectations with librarians, while for librarians, it is a method to understand more about the Chinese student population of library users. The research findings are expected to foster or promote a conversation between librarians and students, let them gain a better understanding of each other, and improve the VRS with the help from both groups.

\section{Confidentiality}

All data obtained from participants will be kept confidential and will only be reported in an aggregate format (by reporting only combined results and never reporting individual ones). All surveys will be password protected, and no one other than the principal investigator will have access to them. The data collected will be stored in the research computer file and the Qualtricssecure database until it has been deleted by the principal investigator.

\section{Participation}

Participation in this research study is completely voluntary. You have the right to withdraw at any time or refuse to participate entirely without jeopardy to your academic status, GPA, or standing with the university. If you desire to withdraw, please close your Internet browser and notify the principal investigator. Or, if you prefer, inform the principal investigator as you leave the questionnaire.

\section{Participant's assurance}

This project has been reviewed by the Institutional Review Board (IRB), which ensures that research projects involving human subjects follow federal regulations.

Any questions or concerns about rights as a research participant should be directed to the Manager of the IRB. Participation in this project is completely voluntary, and participants may withdraw from this study at any time without penalty, prejudice, or loss of benefits.

Any questions about the research should be directed to the Principal Investigator.

\section{Questions about the Questionnaire}

If you have questions regarding the questionnaire, you can contact the principal investigator.

$\underline{\text { Consent to participate in research }}$

Consent is hereby given to participate in this research project. All procedures and/or investigations to be followed and their purpose, including any experimental procedures, were explained. Information was given about all benefits, risks, inconveniences, or discomforts that might be expected.

The opportunity to ask questions regarding the research and procedures was given. Participation in the project is completely voluntary, and participants may withdraw at any time without penalty, prejudice, or loss of benefits. All personal information is strictly confidential, and no 
names will be disclosed. Any new information that develops during the project will be provided if that information may affect the willingness to continue participation in the project.

Questions concerning the research, at any time during or after the project, should be directed to the principal investigator with the contact information provided above. This project and this consent form have been reviewed by the Institutional Review Board, which ensures that research projects involving human subjects follow federal regulations. Any questions or concerns about rights as a research participant should be directed to the Chair of the Institutional Review Board.

I understand the consent form of this research project and would like to continue the questionnaire. (1)

I decline the consent form and do not want to continue the questionnaire. (2)

Skip To: End of Survey If Standard Informed Consent Form Research

Description Introduction This research attempts to col... = I decline the consent form and do not want to continue the questionnaire.

Q2 Are you a Chinese student or a librarian?

Chinese student (1)

Librarian (2)

\section{Display This Question:}

If Are you a Chinese student or a librarian? = Chinese student

Q3 What degree are you pursuing?

Bachelor (1)

Master (2)

Ph.D. (3)

Post-Doctoral (4)

Other (Please clarify) (5) 
Display This Question:

If Are you a Chinese student or a librarian? = Librarian

Q4 What degree do you hold?

Bachelor (1)

Master (2)

Ph.D. (3)

Post-Doctoral (4)

Other (Please clarify) (5)

\section{Display This Question:}

\section{If Are you a Chinese student or a librarian? = Chinese student}

Q5 Do you know that your library provides virtual reference service (VRS, e.g. Ask-a-Librarian online)?

Yes, I know that my library provides VRS to its users. (1)

No, I don't know my library provides VRS to its users. (Please clarify the reason) (2)

I don't care whether my library provides VRS to its users. (Please clarify the reason) (3)

\section{Display This Question: \\ If Are you a Chinese student or a librarian? = Chinese student \\ And Do you know that your library provides virtual reference service (VRS)? = Yes, I know that my library provides VRS to its users.}


Q6 Why use VRS?

I am away from library and cannot be there physically. (1)

VRS is faster and more convenient than traditional reference service (e.g.: no need to go to the information desk, can ask questions through phone, etc.). (2)

I do not need instant answer, VRS can provide asynchronous answers to me. (3)

I am nervous when speaking with librarians face-to-face, it is better for me to ask questions online. (4)

Other (Please clarify) (5)

Display This Question:

If Are you a Chinese student or a librarian? = Chinese student

And Do you know that your library provides virtual reference service (VRS)? = Yes, I know that my library provides VRS to its users.

Q7 Please select types of VRS that you use the most.

Online chat (1)

Email (2)

Text (3)

Telephone (4)

Other (Please clarify) (5) 


\section{Display This Question:}

If Are you a Chinese student or a librarian? = Chinese student

And Do you know that your library provides virtual reference service (VRS)? = Yes, I know that my library provides VRS to its users.

Q8 How often do you use VRS?

\begin{tabular}{|c|c|c|c|}
\hline & Within a day (1) & Within a week (2) & Within a month (3) \\
\hline$\otimes 1-3$ times $(1)$ & & & \\
\hline Q4-6 times (2) & & & \\
\hline$\otimes 7-9$ times (3) & & & \\
\hline $\begin{array}{c}\otimes \text { More than } 9 \text { times } \\
\text { (4) }\end{array}$ & & & \\
\hline
\end{tabular}

\section{Display This Question: \\ If Are you a Chinese student or a librarian? = Chinese student \\ And Do you know that your library provides virtual reference service (VRS)? = Yes, I know that my library provides VRS to its users.}

Q9 What types of questions have you asked most often through VRS?

Academic question (e.g.: finding library materials) (1)

Directional question (e.g.: location of library study room) (2)

Technical question (e.g.: how to use printer or how to log into the library account) (3) 


\section{Display This Question:}

\section{If Are you a Chinese student or a librarian? = Librarian}

Q10 Are you a reference librarian?

Yes, I am a reference librarian. (1)

No, reference duty is one part in my job description. (please clarify your other duties, e.g.: cataloging, acquisition, circulation, etc.) (2)

\section{Display This Question:}

\section{If Are you a Chinese student or a librarian? = Librarian}

Q11 Does your library provide VRS to its users?

Yes, my library does provide VRS to its users. (1)

No, my library does not provide VRS to its users. (Please clarify the reason) (2)

\section{Display This Question:}

\section{If Are you a Chinese student or a librarian? = Librarian}

Q12 In your opinion, what are the advantages and disadvantages of providing VRS to users? Please drag the items to the groups that show your understanding of either "advantage" or "disadvantage".

\begin{tabular}{c|c} 
Advantage & Disadvantage \\
\hline $\begin{array}{l}\text { It is a way to provide } \\
\text { reference service in an Internet }\end{array}$ & $\begin{array}{r}\text { It is a way to provide } \\
\text { reference service in an Internet } \\
\text { environment. (1) }\end{array}$ \\
$\begin{array}{l}\text { users to use reference services. (2) } \\
\text { It allows off-campus }\end{array}$ & $\begin{array}{l}\text { It allows off-campus } \\
\text { users to use reference services. (2) }\end{array}$
\end{tabular}


Q___ It allows different devices to be used (e.g.: telephone, iPad). (3)

$\otimes \_$It asks the librarian to find a strategy to deal with simultaneous VRS questions and faceto-face reference questions. (4)

$\otimes$ It costs money and energy to purchase, maintain, and update. (5)

$\otimes$ At times, VRS is not available (e.g.: can't provide online chat when the Internet is shutting down). (6)
Q___ It allows different devices to be used (e.g.: telephone, iPad). (3)

Q___ It asks the librarian to find a strategy to deal with simultaneous VRS questions and faceto-face reference questions. (4)

$\otimes \_$It costs money and energy to purchase, maintain, and update. (5)

$\otimes$ At times, VRS is not available (e.g.: can't provide online chat when the Internet is shutting down). (6)

\section{Display This Question:}

\section{If Are you a Chinese student or a librarian? = Librarian}

And Does your library provide VRS to its users? = Yes, my library does provide VRS to its users.

Q13 Are you familiar with VRS in your library? Please mark your familiarity from 0 to 5, while 0 stands for "Not familiar at all" and 5 stands for "extremely familiar".

Not SomewhatSomewhatFamiliarStronglyExtremely familiarunfamiliar familiar familiar familiar at all

$\begin{array}{llllll}0 & 1 & 2 & 3 & 4 & 5\end{array}$




\section{Display This Question:}

If Are you a Chinese student or a librarian? = Librarian

And Does your library provide VRS to its users? = Yes, my library does provide VRS to its users.

Q14 Please select types of VRS that you use the most.

Online chat (1)

Email (2)

Text (3)

Telephone (4)

Other (Please clarify) (5)

\section{Display This Question:}

If Are you a Chinese student or a librarian? = Librarian

And Does your library provide VRS to its users? = Yes, my library does provide VRS to its users.

Q15 What type of question do you receive most often through VRS?

Academic question (e.g.: finding library materials) (1)

Directional question (e.g.: location of library study room) (2)

Technical question (e.g.: how to use online catalog or how to log into the library account) (3) 


\section{Display This Question:}

\section{If Are you a Chinese student or a librarian? = Chinese student}

And Do you know that your library provides virtual reference service (VRS)? = Yes, I know that my library provides VRS to its users.

Q16 How long do you have to wait until a librarian answers your VRS question? How satisfied are you with the answers? Please drag the items to the groups that show your level of satisfaction.

My questions have been solved and I am satisfy with the answers.

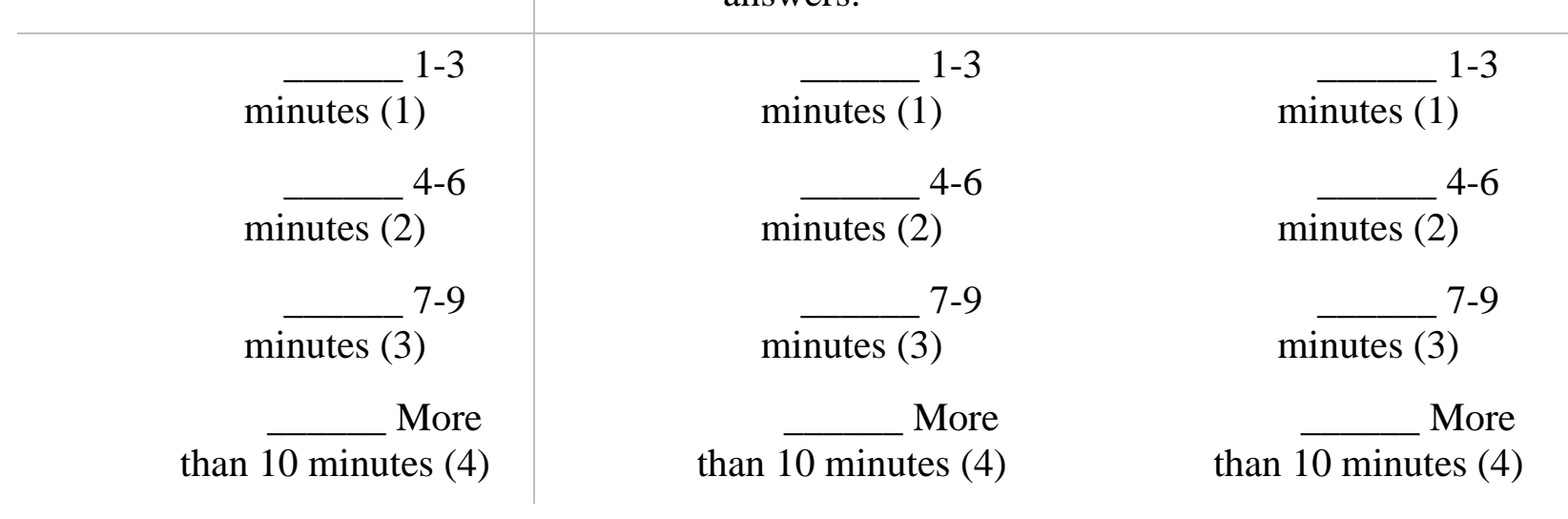

Some of my questions have been solved and I am somehow satisfy with the answers.
My questions have not been solved and I am not satisfy with the answers at all.

\section{Display This Question:}

\section{If Are you a Chinese student or a librarian? = Chinese student}

And Do you know that your library provides virtual reference service(VRS)? = Yes, I know that my library provides VRS to its users. 
Q17 How satisfied are you with your English language when using VRS? Do you think your language skills cause trouble when using VRS?

\begin{tabular}{l|cccccc} 
& $\begin{array}{c}\text { Extremely } \\
\text { satisfied } \\
\text { and does } \\
\text { not cause } \\
\text { trouble (1) }\end{array}$ & $\begin{array}{c}\text { Moderately } \\
\text { satisfied } \\
\text { and might } \\
\text { not cause } \\
\text { trouble (2) }\end{array}$ & $\begin{array}{c}\text { Satisfied, } \\
\text { but might } \\
\text { cause } \\
\text { trouble (3) }\end{array}$ & $\begin{array}{c}\text { Slightly } \\
\text { dissatisfied } \\
\text { and might } \\
\text { cause } \\
\text { trouble (4) }\end{array}$ & $\begin{array}{c}\text { Moderately } \\
\text { dissatisfied } \\
\text { and slightly } \\
\text { cause } \\
\text { trouble (5) }\end{array}$ & $\begin{array}{c}\text { Extremely } \\
\text { dissatisfied } \\
\text { and does } \\
\text { cause } \\
\text { trouble (6) }\end{array}$ \\
\hline $\begin{array}{c}\text { English } \\
\text { Skill: }\end{array}$ \\
$\begin{array}{c}\text { Listening } \\
\text { (1) }\end{array}$ \\
English \\
Skill: \\
Speaking \\
(2)
\end{tabular}

\section{Display This Question:}

\section{If Are you a Chinese student or a librarian? = Librarian}

And Does your library provide VRS to its users? = Yes, my library does provide VRS to its users.

Q18 What is the average time it takes for you to answer VRS questions? Are you satisfied with your answers? Please drag the items to the groups that show your level of satisfaction.

\begin{tabular}{c|cc} 
I am satisfy with my answers. & $\begin{array}{c}\text { I am somehow satisfy with } \\
\text { my answers. }\end{array}$ & $\begin{array}{c}\text { I am not satisfy with my } \\
\text { answers at all. }\end{array}$ \\
\hline Within & $\begin{array}{c}\text { Within } \\
\text { 1-3 minutes (1) }\end{array}$ & $1-3$ minutes $(1)$
\end{tabular}




\begin{tabular}{|c|c|c|}
\hline 4-6 minutes $(2)$ & 4-6 minutes $(2)$ & 4-6 minutes $(2)$ \\
\hline 7-9 minutes (3) & 7-9 minutes (3) & 7-9 minutes $(3)$ \\
\hline an $\frac{\text { More }}{10 \text { minutes }(4)}$ & than $\frac{\text { More }}{10 \text { minutes (4) }}$ & than $\frac{\text { More }}{10 \text { minutes (4) }}$ \\
\hline
\end{tabular}

\section{Display This Question:}

If Are you a Chinese student or a librarian? = Librarian

Q19 Are you able to understand the question and provide the answer if the question has typographical or grammar problems?

Yes (1)

No (2)

It depends (3)

\section{Display This Question:}

\section{If Are you a Chinese student or a librarian? = Chinese student}

Q20 Can you easily find VRS (in most cases it's "Ask-a-librarian") on the library website?

Yes (1)

No (2)

\section{Display This Question:}


Q21 Do you think Frequently Asked Question (FAQ) pages, research guides, and path finders are helpful for you to find library materials before you ask for help?

Yes (1)

No (2)

Maybe (Please clarify) (3)

\section{Display This Question:}

\section{If Are you a Chinese student or a librarian? = Chinese student}

Q22 Are you familiar with the library online catalog? Do you search the online catalog before asking for help? Please scale your familiarity to the online catalog and whether or not you will search it first below. (Taking "0" as "definitely not familiar" and "will not search the catalog first", while taking "5" as "definitely familiar" and "will search the catalog first".)

$\begin{array}{llllll}0 & 1 & 2 & 3 & 4 & 5\end{array}$

\begin{tabular}{r}
\hline I am familiar with library online catalog () \\
\hline I will search library online catalog first \\
before I turn to help ()
\end{tabular}

\section{Display This Question:}

\section{If Are you a Chinese student or a librarian? = Chinese student}

Q23 Are you able to find your wanted materials by using the library online catalog?

Yes (1)

No (2) 


\section{Display This Question:}

\section{If Are you able to find your wanted materials by using the library online catalog? = Yes}

Q24 After you find your materials, do you still want to use VRS?

No, I will not use VRS. (1)

Yes, I still want to use VRS. (Please clarify the reason) (2)

\section{Display This Question: \\ If Are you a Chinese student or a librarian? = Librarian \\ And Does your library provide VRS to its users? = Yes, my library does provide VRS to its users.}

Q25 Do you think users can easily find VRS through the library website?

Yes (1)

No (2)

\section{Display This Question: \\ If Are you a Chinese student or a librarian? = Librarian}

Q26 Are the "FAQ" page, research guides, path finders, etc. on the library website updated regularly? Do you think they can help users understand library services?

Yes, we update FAQ, research guides, path finders, etc. regularly, and we think they can help users understand library services. (1)

No, we do not update FAQ, research guides, path finders, etc. regularly, and we do not think they can help users understand library services. (2)

Yes, we update FAQ, research guides, path finders, etc. regularly. However, we do not rely only on library website; we have other ways to let users understand library services. (Please clarify) (3) 


\section{Display This Question:}

\section{If Are you a Chinese student or a librarian? = Librarian}

Q27 Do you direct users to the library online catalog and teach them how to search materials through the online catalog?

Yes, I often direct users to the library online catalog and teach them how to search materials from there. (1)

I teach users to search materials through the library online catalog, however, I prefer to direct them to other ways to other ways to find materials (e.g.: interlibrary loan). (2)

It depends on the types of questions I get from users. Sometimes I will direct them to the library online catalog while sometimes I do not need to use library online catalog. (3)

No, I often give direct answer to users without directing them to the library online catalog. (4)

\section{Display This Question:}

\section{If Are you a Chinese student or a librarian? = Chinese student}

Q28 Do you want your library to provide VRS that focuses on international students? If yes, what additional service(s) would you want the library to add? 
Q29 Do you provide VRS that focuses on international students? If yes, please clarify the types of VRS, if no, what VRS would you like to add?

Yes, we do provide VRS that focuses on international students. (1)

No, we do not provide VRS that focuses on international students. (2)

\begin{abstract}
About the author
Xiaojie Duan is Catalog Librarian and Assistant Professor at the University of Southern Mississippi Libraries. She has an MLIS degree from the University of Wisconsin-Milwaukee. Her research topics include cataloging and classification issues, information access and retrieval, library services to international students, and more.
\end{abstract}

